\title{
THE BLOOD GROUPS OF THE PEOPLE OF EGYPT
}

\author{
JOYCE A. DONEGANI, KARIMA A. IBRAHIM, ELIZABETH W. IKIN \\ and A. E. MOURANT
}

Blood Group Reference Laboratory, Lister Institute, London, S.W.I and State Serum Institute, Cairo

Received 5.x.49

By means of its land connection with Asia, Egypt is one of the gateways through which large movements of people into and out of Africa have taken place. Physical anthropologists nevertheless point to a general persistence of physical type in Egypt throughout many thousands of years. A comparison of the blood groups of the people of Egypt with those of their neighbours must therefore be of great interest. Numerous studies of their $\mathrm{ABO}$ and $\mathrm{MN}$ groups, summarised by Boyd (1939), had already been made but nothing was known of their $\mathrm{Rh}$ groups.

TABLE I

The $\mathrm{A}_{1} \mathrm{~A}_{2} \mathrm{BO}$ groups of 144 Egyptians

\begin{tabular}{|c|c|c|c|c|c|}
\hline Group & Moslems & Christians & $\begin{array}{c}\text { Total } \\
\text { observed }\end{array}$ & $\begin{array}{l}\text { Number } \\
\text { expected }\end{array}$ & $\begin{array}{c}\text { Frequency } \\
\text { observed }\end{array}$ \\
\hline $\begin{array}{l}O \\
A_{1} \\
A_{2} \\
B \\
A_{1} B \\
A_{2} B\end{array}$ & $\begin{array}{r}23 \\
16 \\
4 \\
27 \\
4 \\
0\end{array}$ & $\begin{array}{r}16 \\
28 \\
1 \\
17 \\
7 \\
1\end{array}$ & $\begin{array}{r}39 \\
44 \\
5 \\
44 \\
11 \\
1\end{array}$ & $\begin{array}{r}4 \cdot 1 \\
4 \cdot 2 \\
4 \cdot 4 \\
40 \cdot 1 \\
13 \cdot 4 \\
1 \cdot 7\end{array}$ & $\begin{array}{l}0 \cdot 271 \\
0 \cdot 306 \\
0 \cdot 035 \\
0 \cdot 306 \\
0 \cdot 076 \\
0 \cdot 007\end{array}$ \\
\hline Total & 74 & 70 & 144 & $143 \cdot 9$ & I $\cdot 001$ \\
\hline
\end{tabular}

Gene frequencies

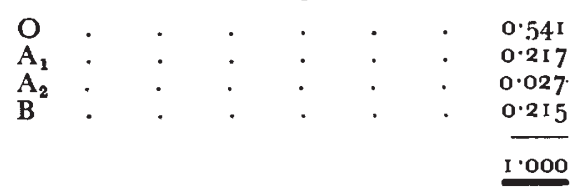

It is well known that the present population of Egypt is markedly heterogeneous. The educated classes in particular have received recent accessions from various other countries, especially around the eastern Mediterranean ; in the opinion of some anthropologists one of the oldest established elements in the population, and one bearing a close resemblance in physical characters to the ancient Egyptians of Pharaonic times, consists of those people in Upper Egypt who, 
TABLE 2

The MNS groups of 144 Egyptians

\begin{tabular}{|c|c|c|c|c|c|}
\hline Group & Moslems & Christians & $\begin{array}{c}\text { Total } \\
\text { observed }\end{array}$ & $\begin{array}{l}\text { Number } \\
\text { expected }\end{array}$ & $\begin{array}{c}\text { Frequericy } \\
\text { observed }\end{array}$ \\
\hline $\begin{array}{l}\text { MS } \\
\text { Ms } \\
\text { MNS } \\
\text { MNs } \\
\text { NS } \\
\text { Ns }\end{array}$ & $\begin{array}{r}11 \\
4 \\
20 \\
16 \\
6 \\
17\end{array}$ & $\begin{array}{r}16 \\
8 \\
17 \\
17 \\
3 \\
9\end{array}$ & $\left.\begin{array}{r}\left.\begin{array}{r}27 \\
12\end{array}\right\} 39 \\
37 \\
33\end{array}\right\} 70$ & 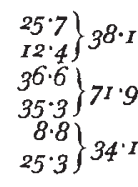 & $\begin{array}{l}0.187 \\
0 \cdot 083 \\
0 \cdot 257 \\
0 \cdot 229 \\
0 \cdot 062 \\
0 \cdot 181\end{array}$ \\
\hline Total & 74 & 70 & 144 & $I 44^{\cdot} \cdot I$ & 0.999 \\
\hline
\end{tabular}

Chromosome frequencies

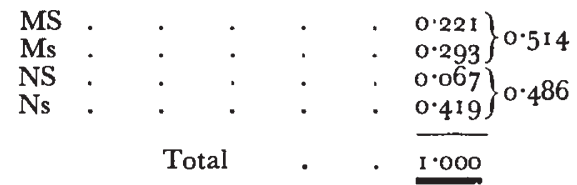

TABLE 3

The $\mathrm{Rh}$ groups of 184 Egyptians

\begin{tabular}{|c|c|c|c|c|}
\hline Phenotype & $\begin{array}{l}\text { Commonest } \\
\text { genotype }\end{array}$ & $\begin{array}{l}\text { Number } \\
\text { observed }\end{array}$ & $\begin{array}{l}\text { Number } \\
\text { expected }\end{array}$ & $\begin{array}{c}\text { Frequency } \\
\text { observed }\end{array}$ \\
\hline $\begin{array}{l}\text { CCDee * } \\
\text { CcDee } \\
\text { CcDEe } \\
\text { ccDEE } \\
\text { ccDEe } \\
\text { ccDee } \\
\text { ccDuee } \\
\text { ccddee }\end{array}$ & $\begin{array}{l}\mathrm{CDe} / \mathrm{CDe} \\
\mathrm{CDe} / \mathrm{cde} \\
\mathrm{CDe} / \mathrm{cDE} \\
\mathrm{cDE} / \mathrm{cDE} \\
\mathrm{cDE} / \mathrm{cde} \\
\mathrm{cDe} / \mathrm{cde} \\
\mathrm{cD}{ }^{u} / \mathrm{cde} \\
\mathrm{cde} / \mathrm{cde}\end{array}$ & $\begin{array}{l}47 \\
73 \\
15 \\
1 \\
16 \\
20 \\
1.09 \dagger \\
10.91 \dagger\end{array}$ & $\begin{array}{r}45 \cdot 0 \\
75.7 \\
16.3 \\
1.5 \\
13.7 \\
19.9 \\
1 \cdot 1 \\
10.8\end{array}$ & $\begin{array}{l}0.255 \\
0.397 \\
0.081 \\
0.005 \\
0.087 \\
0.109 \\
0.006 \\
0.059\end{array}$ \\
\hline \multicolumn{2}{|c|}{ Totals } & I 84 & I $84 \cdot 0$ & 0.999 \\
\hline
\end{tabular}

* See Mourant (1949).

$\dagger$ Out of 12 samples found on preliminary testing to be cde/cde, I I were further tested for the presence of the $\mathrm{D}^{u}$ antigen which was found in one of them. The remaining one had been tested before the test for $\mathrm{D}^{u}$ had become standard practice. It has therefore been partitioned between the two phenotypes in the proportion of $10: \mathrm{I}$.

$$
\begin{aligned}
& \text { Chromosome frequencies }
\end{aligned}
$$

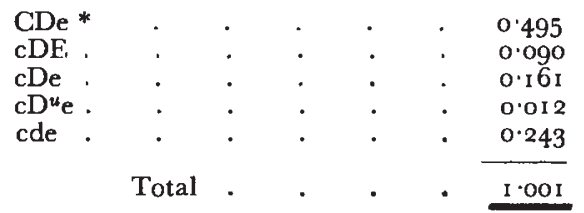

* The anti-C serum used had the specificity anti-C+anti-C ${ }^{w}$. CDe therefore includes. any $\mathrm{C}^{\boldsymbol{w}}$ De which may have been present in the population. 
at the present time, practise the rites of the Coptic Christian Church. The heterogeneity of modern Egyptians is reflected in the variations in the frequencies of the $\mathrm{ABO}$ blood groups.

Whilst we should have preferred to confine our studies to one or more groups of people selected on anthropological grounds we have hitherto been unable to obtain sufficient suitable specimens for this purpose : and the results obtained by examining specimens obtained through a variety of channels and selected in different ways show, nevertheless, sufficient homogeneity from the blood group point of view and at the same time are of such great interest and show such a great difference from all other populations so far examined, as to make it desirable to publish this account at once rather than to delay in order to add to our data. We hope that we ourselves and other workers will later be able to supplement these by many more tests.

In $1947 \mathrm{Dr} R$. R. Race determined the $\mathrm{ABO}$ and $\mathrm{Rh}$ groups of 20 Moslems and 20 Coptic Christians of Egypt, from specimens of blood kindly sent through the courtesy of Brigadier H. T. Findlay. Dr Race has kindly allowed us to use these results. Subsequently one of us (K. A. I.) was able to collect specimens from a considerable number of Egyptians resident in London. Then we received from Professor J. H. Fisher two consignments of specimens obtained from Coptic Christians of Upper Egyptian origin. These were specially selected from the anthropological point of view and as far as could be ascertained by careful questioning, none of the subjects had any known ancestors born outside Egypt. The numbers of them are too small at present for separate statistical treatment, but to enable them to be used in any future study in combination with results obtained from other people selected in a similar manner, their full blood groups are listed in table 4. The remaining Christians tested are probably comparable but we have no guarantee of this other than the similarity of their blood-group frequencies.

A small number of the Moslems are known to have had some non-Egyptian ancestors, but an attempt to eliminate such persons from our lists would have been very difficult and liable to lead to errors due to bias arising from the known results of the tests, errors possibly greater than have been introduced by their retention. We thus had available altogether the results of testing I 84 persons, 94 Moslems and 90 Christians. All of these were tested for $\mathrm{Rh}$ (with anti-C+anti-C $\mathrm{C}^{w}$, anti-D, anti-E, anti-c and anti-e). In the first 4o tests carried out by Dr Race no distinction was possible, owing to the age of the specimens, between $A_{1}$ and $A_{2} ;$ since the total frequencies of the groups $\mathrm{O}, \mathrm{A}, \mathrm{B}$, and $\mathrm{AB}$ among these 40 differed little from those found in the subsequent 144 , the former have been disregarded in our $\mathrm{ABO}$ calculations. The first 40 were also not tested for $\mathrm{MN}$ and S. Among all but the same 40, apparent D-negatives were subjected to an indirect Coombs test with a strong incomplete anti-D serum in order to detect the $\mathrm{D}^{u}$ antigen if present. 
From our results we have calculated gene frequencies by methods already used by some of us (Chalmers, Ikin and Mourant, I949; Prasad, Ikin and Mourant, I949) and from these the expected phenotype numbers have been calculated and compared with the observed values. The $\mathrm{Rh}$ calculations are, however, somewhat complicated by the fact that the group ccee here includes three phenotypes, ccDee, $\mathrm{ccD}^{\mu} \mathrm{ee}$ and $\mathrm{ccddee}$. The chromosome frequencies $\mathrm{cDe}, \mathrm{cD}^{\mu} \mathrm{e}$ and cde were therefore calculated from the frequencies of these phenotypes and a proportional correction made so that the sum of

TABLE 4

Sixty-two anthropologically selected Copts of Upper Egyptian ancestry classified according to $\mathrm{A}_{1} \mathrm{~A}_{2} \mathrm{BO}$ and $\mathrm{MNS}$ groups and probable $\mathrm{Rh}$ genotypes

\begin{tabular}{|c|c|c|c|c|c|c|c|c|}
\hline $\begin{array}{l}\text { Probable Rh } \\
\text { genotype }\end{array}$ & \multicolumn{2}{|l|}{$\mathrm{AB}$} & \multicolumn{2}{|l|}{$A_{1}$} & \multicolumn{2}{|l|}{ B } & \multicolumn{2}{|l|}{ O } \\
\hline $\mathrm{CDe} / \mathrm{CDe}$ & $\begin{array}{l}\text { Ms } \\
\text { MNS } \\
\text { MNs }\end{array}$ & $\begin{array}{l}\text { I } \\
\text { I }\end{array}$ & $\begin{array}{l}\text { Ms } \\
\text { MNS } \\
\text { MNs } \\
\text { Ns }\end{array}$ & $\begin{array}{l}\text { I } \\
2 \\
\text { I } \\
\text { I }\end{array}$ & $\begin{array}{l}\text { MS } \\
\text { MNS } \\
\text { MNs }\end{array}$ & $\begin{array}{l}\text { I } \\
\text { I } \\
2\end{array}$ & $\begin{array}{l}\text { MS } \\
\text { MNS } \\
\text { MNs }\end{array}$ & $\begin{array}{l}\text { I } \\
\text { I }\end{array}$ \\
\hline $\mathrm{CDe} / \mathrm{cDE}$ & $\ldots$ & & $\begin{array}{l}\text { MNS } \\
\text { MNs }\end{array}$ & $\begin{array}{l}1 \\
2\end{array}$ & $\cdots$ & & $\cdots$ & \\
\hline $\mathrm{CDe} / \mathrm{cde}$ & $\begin{array}{l}\text { MS } \\
\text { MNs }\end{array}$ & I & $\begin{array}{l}\text { MS } \\
\text { Ms } \\
\text { MNS } \\
\text { MNs }\end{array}$ & $\begin{array}{l}2 \\
3 \\
3 \\
3\end{array}$ & $\begin{array}{l}\text { MS } \\
\text { Ms } \\
\text { MNS } \\
\text { MNs }\end{array}$ & $\begin{array}{l}\mathrm{I} \\
3 \\
\mathrm{I} \\
\mathrm{I}\end{array}$ & $\begin{array}{l}\text { MNS } \\
\text { NS } \\
\text { Ns }\end{array}$ & $\begin{array}{l}2 \\
2 \\
1\end{array}$ \\
\hline cDE/cde & MNS & I & $\ldots$ & & $\begin{array}{l}\text { MS } \\
\text { MNs } \\
\text { Ns }\end{array}$ & $\begin{array}{l}\text { I } \\
\text { I }\end{array}$ & $\begin{array}{l}\text { MS } \\
\text { MNs }\end{array}$ & $\begin{array}{l}2 \\
1\end{array}$ \\
\hline cDe/cde & Ns & I & $\begin{array}{l}\text { MS } \\
\text { Ns }\end{array}$ & $\begin{array}{l}2 \\
I\end{array}$ & Ns & I & $\begin{array}{l}\text { MS } \\
\text { MNS } \\
\text { MNs }\end{array}$ & $\begin{array}{l}\text { I } \\
\text { I }\end{array}$ \\
\hline $\mathrm{cD}^{\mathrm{u}} \mathrm{e} / \mathrm{cde}$ & $\ldots$ & & $\ldots$ & & MNs & I & $\cdots$ & \\
\hline cde/cde & $\cdots$ & & Ns & 2 & MNS & I & MS & I \\
\hline
\end{tabular}

* All the persons classified as $\mathrm{AB}$ were $\mathrm{A}_{\mathbf{1}} \mathrm{B}$ with the exception of this one who was $\mathrm{A}_{\mathbf{2}} \mathrm{B}$.

the chromosome frequencies should agree with the total frequency of ce chromosomes found by the methods described by Chalmers, Ikin and Mourant (1949). These methods are adopted as expeditious though known not to be fully efficient.

We have shown in tables I and 2 separate totals of Christians and Moslems but have based all our calculations on the totals of both. The differences in $\mathrm{Rh}$ phenotype frequencies are not given because they were (table 3) well below the level of significance. Even in the case of $\mathrm{ABO}$ and $\mathrm{MN}$, where they are greater, they are still not significant.

We do not propose in this paper to undertake a critical study of 
the $\mathrm{ABO}$ and $\mathrm{MN}$ groups of the population of Egypt. Among the wide range of frequencies found by different observers and quoted by Boyd (1939) it is difficult to select the most reliable but it is clear that our results do not differ greatly from those of most previous workers. As a rough estimate the average percentage gene frequencies found by others among Christians are A, 25; B, 21; O, 54; and

\section{Rh CHROMOSOME FREQUENCIES (PER CENT) IN EAST AFRICA, WESTERN ASIA AND EASTERN EUROPE.}

Based on the present study, on the work of Kayssi (1949), Race, Sanger. Lawler and Keetch (1948), and on unpublished data of Ikin and Mourant.

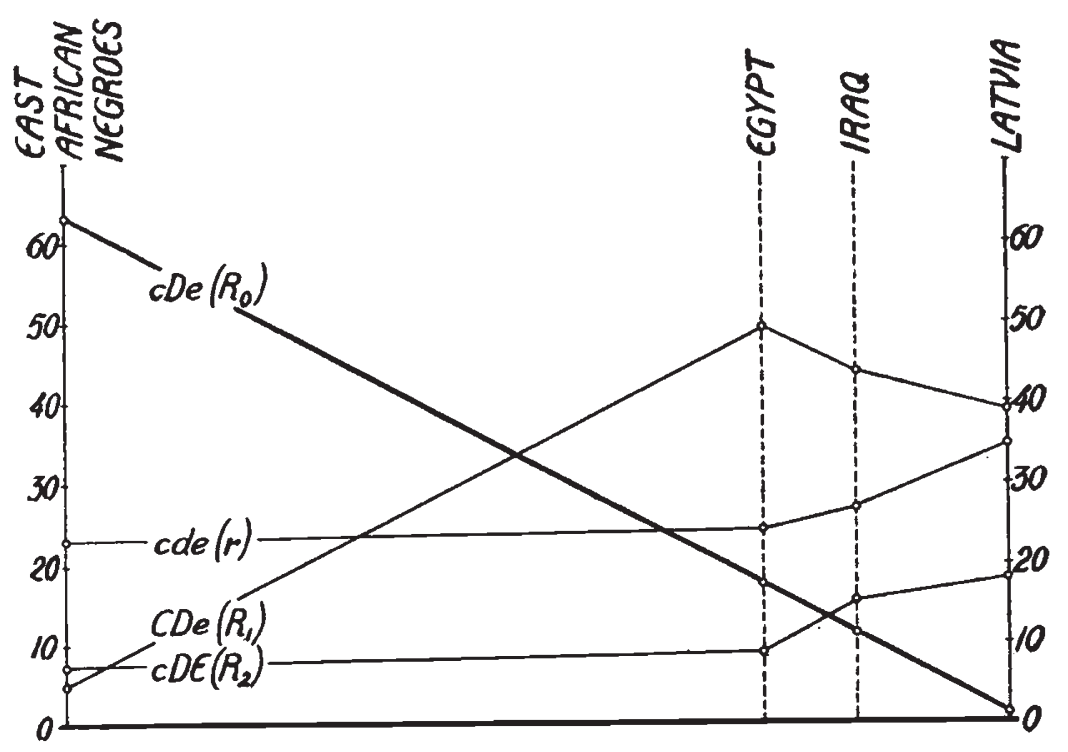

The diagram shows the fall in frequency of the cDe chromosome from south to north, the maximum frequency of $\mathrm{CDe}$ in Egypt, and the corresponding variations in frequency of the other common Rh chromosomes. The spacing on the horizontal scale is arbitrarily arranged so as to make the frequencies of cDe fall on a straight line.

Fig. 1.

among Moslems A, $28 ; \mathrm{B}, 2 \mathrm{I} ; \mathrm{O}, 5 \mathrm{I}$; whereas our overall figures show A, 24; B, 21 ; O, 54, with, in fact, a higher frequency of A among Christians than among Moslems. We have found the ratio of the phenotype frequencies $A_{2} / A_{1}$, to be $0 . I$ I which is lower than the values $(0 \cdot 17$ to $0 \cdot 24)$ found by previous workers and quoted by Boyd (1939). From Boyd's compilation of MN data the gene percentages for both Moslems and Christians are roughly $\mathrm{M}, 53$; 
$\mathrm{N}, 47$ whereas we find $\mathrm{M}, 5^{\mathrm{I}} ; \mathrm{N}, 49$. Our determinations of the Ss subgroups of the MN system are the first to be published for Egyptians.

In their $\mathrm{Rh}$ phenotype frequencies the Egyptians differ very greatly from all other populations yet examined except the people of Baghdad (Kayssi, I 949) to whom they show a moderate degree of resemblance. The outstanding feature of the Egyptians is their very high $\operatorname{CDe}\left(\mathrm{R}_{1}\right)$ frequency, considerably higher than that of any population in Europe for which figures have been published, and very much higher than some of us have found in testing numerous other African populations (Donegani, Ikin and Mourant, unpublished). At the same time they show a higher $c \operatorname{De}\left(R_{0}\right)$ frequency than any non-Negro population nearer than Eastern Asia. While any final conclusion must depend on the examination of many other Near Eastern populations, an examination of fig. I in which the Rh chromosome frequencies of East Africans, Egyptians, Iraqui and Europeans (Latvians) are compared suggests the following tentative conclusions :

(i) The Egyptians represent a basic or culminating population type with a small Negro admixture. (ii) In Iraq we find the Egyptian type, still with a certain Negro admixture, considerably diluted with European stock; indeed, in view of recent observations on the $\mathrm{Rh}$ groups of Indians (Prasad, Ikin and Mourant, I94.9) we can probably say that the dilution was with Indo-European stock.

\section{SUMMARY}

The $\mathrm{A}_{1} \mathrm{~A}_{2} \mathrm{BO}$ and MNS blood groups of 144 Egyptians, and the full $\mathrm{Rh}$ phenotypes of 184 Egyptians have been determined. The Egyptians show a high frequency (2 I per cent.) of the B gene. Their MN distribution does not differ significantly from that found in Europe and in other parts of Africa. Their Rh distribution is different from any other yet discovered, with a high frequency of CDe or $\mathbf{R}_{\mathbf{1}}$ (49 per cent.) which is probably an ancient Egyptian characteristic, and with 16 per cent. of $\mathrm{cDe}\left(\mathrm{R}_{\mathbf{0}}\right)$ chromosomes, a feature probably derived from an admixiure of Negro stock.

Acknowledgments.-We wish to thank Brigadier H. T. Findlay, Prof. J. H. Fisher, Dr J. N. Marshall Chalmers and many other persons who helped in the collection and transport of the specimens for this work; also Dr R. R. Race for allowing us to use the results of his tests on 40 Egyptians.

\section{REFERENCES}

BOYD, w. c. 1939. Tab. Biol., 17.

chalmers, J. n. m., ikin, elizabeth w., and mourant, A. e. ig49. Am. F. Phys. Anthrop., N.S., 7, 529-544.

Kayssi, A. I. 1949. Am. J. Phys. Anthrop., N.S., 7, 549-551.

MOURANT, A. E. 1949. Nature, I63, 9 I3.

PRASAd, c. h., ikin, elizabeth w., And mourant, A. e. 1949. Am. F. Phys. Anthrop., N.S., 7, 553-558.

RACE, R. R., SANGER, RUTH, LAWLER, SYLVIA D., AND KEETCH, D. v. 1948. Ann. Eugen., 14, I34. 